\title{
Abating feral Africanized honey bees (Apis mellifera $L$ ) to enhance mating control of European queens $t$
}

\author{
RG Danka 1, GM Loper 2, JD Villa, JL Williams 1, \\ EA Sugden ${ }^{3^{*}}$, AM Collins ${ }^{3}$, TE Rinderer ${ }^{1}$ \\ 1 USDA, ARS Honey-Bee Breeding, Genetics and Physiology Laboratory, \\ 1157, Ben Hur Road, Baton Rouge, LA 70820; \\ 2 USDA, ARS Carl Hayden Bee Research Center, 2000, East Allen Road, Tucson, AZ 85719; \\ 3 USDA, ARS Subtropical Agricultural Research Laboratory, Honey Bee Research Unit, \\ 2413, East Highway 83, Weslaco, TX 78596, USA
}

(Received 16 August 1993; accepted 17 May 1994)

\begin{abstract}
Summary - Abatement of local feral honey-bee colonies was tested as a method to increase the mating control of European queens produced in an Africanized area. Feral colonies within $2 \mathrm{~km}$ of a commercial mating apiary at Belén, Guanacaste Province, Costa Rica were targeted. Thirty-eight feral colonies were discovered in the $12.5-\mathrm{km}^{2}$ study plot between 13 May and 6 June 1992. Abatement techniques included dispensing avermectin-ivermectin paste (applied manually to the abdominal tergites of drones captured during mating flights) and acephate-treated sucrose syrup bait (retrieved by foragers), and spraying nests directly with pyrethroids. Twenty-one of the known colonies were killed or severely weakened by treatments made between 27 May and 5 June. Mating control in pre-abatement $(n=$ 27 ) and post-abatement $(n=26)$ queens was estimated by measuring changes in morphology and in frequencies of allozymes (malate dehydrogenase-1 100 and hexokinase-1100) of worker progeny relative to reference populations of workers from local Africanized $(n=35)$ and imported European $(n=23)$ colonies. Five of 23 morphological features shifted significantly toward the European form after abatement. Significantly more post-abatement colonies $(85 \%)$ than pre-abatement colonies $(63 \%)$ were classified by multivariate discriminant analysis as European (ie with a probability of Africanization of $<50 \%$ ). Paternal frequencies of both allozymes were shifted significantly toward European frequencies following abatement; malate dehydrogenase decreased $26 \%$ and hexokinase increased $43 \%$. Overall the results suggest that abatement may be useful in augmenting other mating control methods (eg, drone flooding and controlling mating times) but that it is probably not feasible as a unilateral approach to achieving acceptable mating control in heavily Africanized areas.
\end{abstract}

\section{Africanized honey bee / mating control / avermectin / acephate / abatement / pest control}

* Current address: Kentucky State University, Community Research Service, Atwood Research Facility, Frankfurt, KY 40601, USA.

† This paper reports the results of research only. Mention of a proprietary product does not constitute an endorsement or recommendation by the US Department of Agriculture for its use, nor does it imply registration under FIFRA as amended. 


\section{INTRODUCTION}

The production of high quality, properly mated European honey-bee queens in the United States is expected to be hampered as Africanized honey bee become established in southern and coastal areas that form the traditional region of commercial queen production. In the future, use of queens from this region may be restricted by quarantine or market considerations if managed queens mate frequently with Africanized drones. This dilemma could be prevented with methods that enhance the control of natural matings of queens by increasing the ratio of desirable (managed European) drones to undesirable (feral Africanized) drones available for mating. Recent studies have evaluated several possible approaches to enhancing mating control in the absence of access to isolated mating areas. Hellmich et al $(1988,1993)$ and Hellmich and Waller (1990) pursued drone flooding, ie increasing populations of drones available in managed colonies located in or near mating apiaries. Waller et al (1989) mated queens in a semi-isolated desert location during winter when feral colonies had no or few drones, but when managed colonies had been stimulated to rear many drones. Loper and Fierro (1991) combined drone flooding with capturing and eliminating feral drones in an Africanized area. Each of these efforts resulted in some increase in mating control but none of them completely eliminated mismatings of managed queens to feral drones.

Two novel techniques have been developed recently for suppressing localized populations of undesirable honey bees (especially Africanized bees); they use toxicants delivered by bees back to remote nests. The techniques potentially offer enhanced mating control of managed queens produced in Africanized areas if used to eliminate feral colonies around mating apiaries. In 1 technique, a mixture of avermectin and ivermectin is applied manually to drones captured during mating flights, and the drones are released to return to their colonies (Loper et al, 1987; Loper and Sugden, 1992). The other technique is a baiting system in which acephate in sucrose-honey syrup is retrieved by worker bees (Williams et al, 1989; Danka et al, 1992).

We used these 2 techniques as the principal components of an abatement effort that targeted feral Africanized colonies around a commercial mating apiary. Our objective was to determine whether a simple, low- to moderate-intensity abatement program alone would substantially increase mating control of managed queens produced in an Africanized area. The general test plan was to first conduct a group of pre-abatement matings of European queens, and then eliminate as many local feral colonies as possible within a reasonable time frame, and finally mate another group of European queens. The change in mating control of queens following abatement was estimated by comparing morphometrics and enzyme frequencies of worker progeny of these groups of queens with characteristics of workers from European and Africanized parental populations. The test was conducted so as to approximate an abatement program that a commercial queen producer might attempt, ie 1) to expend some effort to locate feral colonies near the mating apiary; 2) to destroy known feral colonies directly when possible; 3 ) to attempt areawide colony suppression using drone-mediated treatments; and 4) to use worker-mediated treatments from baits against inaccessible colonies and unlocated colonies.

\section{MATERIALS AND METHODS}

\section{Study area}

The study area was a circle of 2-km radius that surrounded a commercial queen mating apiary at Belén, Guanacaste Province, Costa Rica $\left(10^{\circ} 25^{\prime} \mathrm{N}, 85^{\circ} 35^{\circ} \mathrm{W}\right)$. This area met the criteria of having an established mating apiary, a feral 
Africanized population, no other known managed colonies within about $5 \mathrm{~km}$, and good access because of roads, flat terrain and relatively open vegetation. The local agroecosystem comprised a mixture of cattle pastures and crops, with patches of tropical dry forest (estimated to be $5-10 \%$ of the area) mostly along 3 major intermittent streams.

The mating and abatement portions of the test (mid-May to early June 1992) were timed for the transition between the dry and rainy seasons. This transition period was chosen to enable the use of both drone- and worker-mediated toxicant deliveries to feral colonies within a narrow time frame. Success with drone-mediated treatments requires adequate drone populations in target colonies. Success with worker-mediated treatments requires nectar availability to be sufficiently poor so that active foraging at baits is promoted. The narrow time frame also helped ensure that the populations of managed and feral drones would be stable for the 2 mating groups.

\section{Queen mating and progeny collection}

Fifty queen mating nuclei and 2 drone colonies were moved into the mating apiary on 11 May to initiate the pre-abatement mating. Mating nuclei were given queen cells produced from 2 European queens from whom progeny samples had indicated frequencies of $M d h-1^{100}$ at $<0.25$ and $H K-1100$ at $\approx 1.00$. The 2 queen sources thus were chosen to increase the probability of obtaining daughterqueens homozygous for European-associated forms of $M d h-1$ and $H k-1$ so that we could separate progeny with European paternity from those with Africanized paternity. Drones in all colonies in the mating apiary were the progeny of a random group of queens produced from among 23 imported European queens (including the 2 queen mothers). European drone populations were maintained relatively small (ca 900 drones among all colonies in the apiary both before and after abatement) to increase the likelihood of test queens mating with available feral Africanized drones. Having only small populations of European drones permitted full detection of mating control improvements arising from abatement only.

Mated queens from the pre-treatment group were removed on 25 May and the combs in which they had oviposited were marked. A second group of queen cells produced from the same 2 queen mothers was added to the nuclei between 28 and
31 May. Virgin queens and drones were prevented from flying (by using queen excluders) until 6 June during treatment of feral colonies. Progeny samples for the pre-abatement $(n=27)$ and post-abatement $(n=26)$ matings were collected from combs of emerging brood on 13 June and 9 July, respectively. Samples for morphometric analysis were stored in $70 \%$ ethanol; samples for enzyme analysis were stored in liquid nitrogen. Samples of adult workers from feral Africanized and managed European colonies were collected directly from combs or nest entrances.

\section{Locating, sampling and abating feral colonies}

We searched for feral colonies and swarms from 13 May until 6 June by inquiries of local residents, by observing openings in trees and by tracking foragers as they departed from syrup baits. Intensive surveys were conducted in patches of riparian forest, in treelines along fences, and at isolated large trees. Quadrants of the study zone initially were searched sequentially, permitting various insecticide treatments to begin in some quadrants while searches continued in others. We usually dedicated less than 1 person-hour searching for any particular colony that was indicated by foraging activity on baits.

Twenty-six feral colonies were sampled. Also designated and sampled as resident Africanized bees were 9 hived but otherwise unmanaged colonies discovered at the periphery of the study area. These colonies had minimal drone flight, and this was prevented with excluders during treatments and during the post-abatement mating period.

Drone-mediated treatments were made in 3 out of 4 quadrants during favorable weather conditions on 27 and 30 May and 1 June; consistently poor afternoon weather prevented treatment in the fourth quadrant. In 1 quadrant on each date, 4 aerial net traps with queen pheromone lures (having crude ethanolic extracts of mature queens) to attract drones (Taylor, 1984) were raised with kites or helium-filled balloons between 15.00 and $17.30 \mathrm{~h}$. The 4 trapping sites were ca $500 \mathrm{~m}$ apart. Drones were collected from the traps at 10- to 30-min intervals, individually treated, and released to return to their colonies (Loper and Sugden, 1992). Drones were dosed by 
hand on abdominal tergites IV-VI with a syringedispensed dab (average of $144 \mu \mathrm{g}$ ai) of a paste mixture (0.37:0.63 ai) of avermectin (Avid $\left.{ }^{\circledR}\right)$ and ivermectin (Zimecterin $\left.{ }^{\circledR}\right)$.

Known feral colonies that survived drone treatments were treated directly with aerosol insecticides sprayed in nest entrances on 1, 4 and 5 June. We used 3 locally available pyrethroid formulations that were labelled for use against honey bees.

Other colonies were treated from 31 May to 5 June by foragers retrieving acephate-treated syrup bait using methods described by Williams et al (1989) and Danka et al (1992). This system was used when we had established foraging by bees at syrup baits, but when colonies could not be located or when nests were inaccessible for direct treatment. Acephate-treated syrup was presented when there were $\geq 100$ bees from an indicated target colony feeding simultaneously at a bait station. To help ensure adequate treatments, as many feeders with acephate syrup were used as there were flight lines from a bait. Syrup with $1000 \mathrm{ppm}(\mathrm{mg} / \mathrm{l})$ acephate (Orthene ${ }^{\circledR} 75 \mathrm{~S}$ ) was used during all but the first 2 treatments (in which $500 \mathrm{ppm}$ acephate was used). To prevent delivering acephate syrup to managed colonies, no treated syrup was dispensed if flight lines to the mating apiary were seen.

\section{Morphometric and enzyme analyses of progeny}

Shifts in morphology of worker progeny of queens were measured as 1 indicator of mating control following abatement. For each of the 4 experimental groups (ie, pre-abatement, post-abatement, feral Africanized and managed European), colony averages (arising from measurements made of 10 bees per colony) were obtained for each of 23 morphological characters and submitted to multivariate discriminant analysis. We used the methods of Daly and Balling (1978) and Daly et al (1982) but excluded wing venation angles 38 and 39 (Rinderer et al, 1993). Analysis of variance and Duncan's multiple range test were used to determine the significance of differences in morphological characters between the 4 groups. The 23 imported European and 35 feral Africanized colonies serve as reference populations in developing a discriminant function, which was used to generate probabilities of Africanized group membership, $P(A)$, of worker progeny from each queen mated before abatement and from each queen mated after abatement. A 1 -tailed $\chi^{2}$ test was used to compare the proportions of progeny of pre-abatement queens and post-abatement queens that were classified as Africanized according to the discriminant function.

Shifts in allelic frequencies of the enzymes malate dehydrogenase $(M D H-1)$ and hexokinase $(H K-1)$ also were measured in worker progeny. Relative allelic frequencies of these enzymes vary among bees of African and of European derivation (Del Lama et al, 1990, and references therein); the allele $M D H-1100$ is present relatively frequently among Africanized bees, and the allele $H K-1100$ is present relatively frequently among European bees. For enzyme analyses, 48 bees from each mated queen and from most feral Africanized colonies, and 12 bees from most European colonies, were processed using cellulose acetate plates (Richardson et al, 1986). Resultant protein banding patterns were assessed to detect queens that were most probably homozygous at the Mdh-1 and Hk-1 loci, and if they were not homozygous, to establish the most probable heterozygous condition of the queen. Two different measurements were made of the paternal $M d h-1$ and $H k-1$ contributions to progeny of each queen. First, paternal alleles for an enzyme could be determined unequivocally for workers of each queen that was homozygous for that enzyme; paternal allelic contributions then were calculated for each queen's mating. Second, for all colonies in which a probable queen genotype was established, a residual paternal frequency was estimated by subtracting the maternal contribution from total frequencies (after assuming equal segregation of the 2 queen alleles). This second set of estimates was made to maximize the information available for each of the 4 groups. Significances of differences in the frequencies of $M d h-1100$ and $H k-1100$ between colonies in the 4 groups were determined by anal$y$ sis of variance of rank-transformed data. Frequencies were transformed because observations within some treatments (especially managed Europeans) were not normally distributed. Pairwise mean comparisons were made with 1-tailed $t$-tests after analysis of variance.

\section{RESULTS}

Thirty-eight feral colonies and 3 swarms were discovered within the $12.6-\mathrm{km}^{2}$ abate- 
ment area. Treatments were directed against 37 of the colonies ( 1 colony absconded after being sampled; swarms were not considered to be a drone source). Application of avermectin-ivermectin to 703 drones in 3 of the 4 quadrants caused visible mortality of workers in 3 colonies within $1 \mathrm{~d}$, and probably decreased drone populations in others without noticeable worker mortality (GM Loper, unpublished observations). Six of 8 colonies treated directly with pyrethroids were killed or weakened severely; they had no flight activity $1 \mathrm{~d}$ after treatment. Eight of 10 colonies treated individually with acephate were killed and the other 2 were weakened. Six other applications of acephate bait were made to undiscovered colonies. A survey immediately prior to the second set of matings showed that out of the 37 known feral colonies, 17 had no activity, 4 were weakened severely, 14 continued to be active, and the fates of 2 colonies were uncertain.

Progeny of those queens mated after abatement had significantly more Europeanlike morphology than did pre-abatement progeny for 5 of 23 characters. For example, of the 5 characters reported by Daly and
Balling (1978) to best discriminate Africanized and European bees (based on F-ratios), and that also best separated treatment groups here, 2 showed significant shifts toward the parental European standard (table I). Measurements for characters in the pre-abatement group were typically intermediate between those of the parental groups as would be expected from European-Africanized hybrid progeny. Multivariate discriminant analysis of morphology further documented a moderate increase in mating control after abatement. More postabatement colonies $(85 \%, 22$ of 26$)$ than pre-abatement colonies $(63 \%, 17$ of 27$)$ were classified as European at $P(\mathrm{~A})<0.50$ $\left(\chi^{2}=3.195 ; d f=1 ; P=0.037\right)$. Similarly, fewer post-abatement colonies $(12 \%, 3$ of $26)$ than pre-abatement colonies $(30 \%, 8$ of 27) were classified as Africanized at the regulatory standard of $P(\mathrm{~A}) \geq 0.99\left(\chi^{2}=\right.$ 2.636; $d f=1 ; P=0.052$ ).

Paternal frequencies of $M d h-1100$ and $H K$ $1^{100}$ were significantly shifted toward European frequencies in the progeny of queens mated after abatement (table II). On average (using data from homozygous queens and from all queens), there was a $26 \%$

Table I. Measurements (mean \pm SE in $\mathrm{mm}$ ) a and results of analyses of variance ${ }^{b}$ of 5 morphological characters of worker progeny of feral Africanized honey bee queens, European queens mated before abatement, European queens mated after abatement, and imported European queens from a field test conducted at Belén, Guanacaste, Costa Rica during May and June 1992.

Morphological character
Queen group

\section{Africanized Pre-abatement Post-abatement European}

Wax-mirror width
Fore-wing length
Wax-mirror length
Sternite length
Femur length

$2.325 \pm 0.010^{b}$
$8.896 \pm 0.023^{c}$
$1.298 \pm 0.008^{b}$
$2.715 \pm 0.012^{b}$
$2.540 \pm 0.008^{c}$

$2.540 \pm 0.008^{\mathrm{c}}$
$2.314 \pm 0.015^{b}$
$9.018 \pm 0.031^{b}$
$1.307 \pm 0.010^{b}$
$2.715 \pm 0.013^{b}$
$2.572 \pm 0.010^{b}$

$2.391 \pm 0.007^{a}$

$9.126 \pm 0.020^{a}$

$1.342 \pm 0.006^{\mathrm{a}}$

$2.770 \pm 0.007^{a}$

$2.611 \pm 0.007^{\mathrm{a}}$

$F$

\footnotetext{
a Derived from samples of 10 bees in each of 23 European colonies, 26 post-abatement colonies, 27 pre-abatement colonies and 35 Africanized colonies; $b$ all $P>F$ are $\leq 0.001$ from tests with $d f=3107$. Queen groups within a row that do not share a common letter differ at $P \leq 0.05$ according to Duncan's multiple range test.
} 
Table II. Paternal frequencies [mean \pm SE $(n)]$ of $M d h-1^{100}$ and $H k-1100$ and results of post analysis of variance tests of frequencies in worker progeny of feral Africanized honey bee queens, European queens mated before abatement, European queens mated after abatement, and imported European queens *.

Enzyme

Queen group

\begin{tabular}{|c|c|c|c|c|}
\hline & Africanized & Pre-abatement & Post-abatement & European \\
\hline- & $-\ldots$ &.-- & - . & -.. \\
\hline \multicolumn{5}{|l|}{ Mdh-1 100, homozygous } \\
\hline queens & $0.84 \pm 0.03(20)^{\mathbf{a}^{\star \star}}$ & ${ }^{*} 0.88 \pm 0.03(7)^{a}$ & $0.69 \pm 0.06(8)^{b}$ & $0.32 \pm 0.08(8)^{\mathrm{c}}$ \\
\hline Mdh-1100, all queens & $0.83 \pm 0.02(30)^{a}$ & $0.84 \pm 0.03(24)^{\mathrm{a}}$ & $0.76 \pm 0.04(25)^{\mathrm{a}}$ & $0.35 \pm 0.05(21)^{b}$ \\
\hline \multicolumn{5}{|l|}{$H k-1100$, homozygous } \\
\hline queens & $0.61 \pm 0.04(13)^{\mathrm{c}}$ & $0.57 \pm 0.05(23)^{c}$ & $0.72 \pm 0.04(24)^{\mathrm{b}}$ & $0.95 \pm 0.03(14)^{a}$ \\
\hline$H k-1100$, all queens & $0.62 \pm 0.03(30)^{\mathrm{c}}$ & $0.58 \pm 0.04(24)^{c}$ & $0.72 \pm 0.03(25)^{\mathrm{b}}$ & $0.91 \pm 0.03(23)^{\mathrm{a}}$ \\
\hline$--\cdot \quad---$ & & & & $\cdots$ \\
\hline
\end{tabular}

decrease in the estimated paternal frequency of $M d h-7^{100}$ and a $43 \%$ increase in the estimated paternal frequency of $H k-1100$ relative to the parental population frequencies. Pre-abatement paternal frequencies were similar to the feral African paternal frequencies for each of the 2 enzymes, whether they were calculated from homozygous queens only or estimated from all samples for which queen genotype could be determined.

\section{DISCUSSION}

Morphological and biochemical markers indicated that mating control of commercially produced European queens was improved following moderate efforts to abate feral Africanized colonies within $2 \mathrm{~km}$ of the mating apiary. More intensive or more widespread abatement efforts probably would have improved control further. Our success in eliminating target colonies was limited to only ca $50-60 \%$ largely by 3 specific circumstances related to timing of the study. First, feral drone populations were relatively small even before abatement, and this impeded making drone-mediated treatments. An average of only $20 \%$ of the number of drones caught daily during a similar test conducted 2 weeks earlier at a site 80 km away (Loper and Sugden, 1992) were caught daily at the Belén site. Second, afternoon rains interfered with drone trapping on several days, and completely prevented drone treatment in 1 quadrant of the study area. Third, these rains stimulated the onset of wet-season blooming, which reduced the relative attractiveness of syrup baits; intense forager activity at baits is critical for delivering lethal doses of acephate (Danka et al, 1992). Each of these hindrances could be overcome substantially if colony suppres- 
sion activities were not undertaken within so strict a time-frame as ours was.

Improvements in mating control found in this test were not sufficient to recommend the abatement program as a unilateral approach for producing European honey bees in a heavily Africanized area. We expect, however, that judicious efforts at suppressing localized feral populations would be advantageous when coupled with efforts to increase managed drone populations. Abatement efforts were not augmented with drone flooding in this test, but we expect that drone flooding would be the primary approach to mating control in normal (nonexperimental) situations. Abatement activities at appropriate intensity could be added at the convenience of queen producers during 1 or more of several key periods during the year. Drone-mediated treatments would be possible in the southern United States in summer or autumn while feral drones are available and when queen production could be curtailed temporarily after the main spring production period. Worker-mediated treatment is most effective during favorable baiting periods (ie times of nectar dearth under conditions allowing flight, particularly in autumn and late winter in the southern United States). Thus, because they are somewhat complementary with respect to times of most effective use, the 2 abatement systems offer options for tailoring approaches to suit specific circumstances.

This study has shown that eliminating sources of undesirable drones near mating apiaries can benefit a stock maintenance program. The advantages and disadvantages (eg, of economics and environmental safety) of an abatement system obviously need careful consideration before such an approach can be recommended, approved for use, or implemented. With further positive information, area-wide feral colony abatement may have use in conjunction with other measures to enhance mating control and ensure the production of desirable stocks of honey bees, particularly in areas threatened by Africanization.

\section{ACKNOWLEDGMENTS}

D Steffens (USDA, ARS, Tucson, AZ) assisted in the field and conducted enzyme analyses; this paper is dedicated to her memory. R Rivera (USDA, ARS, Weslaco, TX) and D Winfrey (USDA, ARS, Baton Rouge, LA) assisted in fieldwork. Commercial beekeeping cooperation was provided by M Gonzales and G Gonzales (APES Agroindustrial SA, Alajuela, Costa Rica). R Riggio (Louisiana State University, Baton Rouge, LA) assisted with morphometric measurements. S Buco (Statistical Resources Inc, Baton Rouge, LA) analyzed the morphological data. F Eischen, $R$ Hellmich, $H$ Shimanuki and $O$ Taylor provided useful comments on the manuscript. This research was sponsored by a USDA Integrated Pest Management Pilot Test grant, and was completed in cooperation with the Louisiana Agricultural Experiment Station.

Résumé - Élimination des abeilles africanisées pour améliorer le contrôle de l'accouplement des reines européennes. Nous avons testé un programme qui doit éliminer, dans une région donnée et sans entraîner de trop fortes dépenses, les colonies sauvages d'abeilles africanisées. Le but est d'améliorer le contrôle de l'accouplement des reines européennes élevées dans une région où les abeilles africanisées sont présentes. Le test comporte 3 phases : i) avant l'élimination : accouplements des reines européennes en présence du nombre normal de mâles africanisés et d'une population réduite de mâles européens provenant de colonies commerciales ; ii) durant le processus d'élimination, qui a été de courte durée pour des raisons expérimentales ; iii) après l'élimination : accouplements des reines au sein d'une population de mâles européens maintenue à un niveau bas. Les colonies sauvages ont été repérées dans un rayon de $2 \mathrm{~km}$ autour d'un rucher commercial de fécondation à Belén, province 
de Guanacaste au Costa Rica. Trois méthodes ont été utilisées pour la destruction. La destruction des colonies a été tentée au niveau de la région par répartition manuelle d'un mélange pâteux d'avermectine et d'ivermectine $(0,37 / 0,63)$ sur les tergites des mâles ( $144 \mu \mathrm{g}$ de substance active $\mathrm{d}^{\prime}$ Avid ${ }^{\circledR}$ et de Zimecterin ${ }^{\circledR}$ par mâle) piégés à l'aide de filets pendant les vols de fécondation (Loper et Sugden, 1992). Les colonies restantes accessibles ont été directement pulvérisées avec un aérosol à base de pyrèthre. Les colonies non accessibles ont été traitées par l'intermédiaire des butineuses, auxquelles on a fait récolter un leurre constitué de sirop et de miel additionné de 500 ou 1000 ppm d'acétate (Orthene ${ }^{\oplus} 75$ S) (Williams et al, 1989; Danka et al, 1992). La descendance issue des accouplements après l'élimination ( $n=$ 26) a été comparée à celle issue des accouplements avant l'élimination $(n=27)$. Des reines d'abeilles africanisées des alentours $(n=35)$ et de colonies européennes importées ( $n=23)$ ont servi de témoins. Le contrôle de l'accouplement a été estimé par 2 méthodes : nous avons d'abord déterminé 23 caractères morphologiques sur 10 ouvrières par colonie. Pour chaque caractère les mesures ont été comparées parmi les 4 populations de colonies expérimentales à l'aide de l'analyse de variance. La probabilité d'africanisation $\left(P_{\mathrm{A}}\right)$ de chacune de ces populations a été classée à l'aide de l'analyse discriminante multivariée (Rinderer et al, 1993). Nous avons aussi déterminé les fréquences des allozymes de la malate déhydrogénase- $1^{100}$ et de l'héxokinase-1100 par des gels d'acétate-cellulose (Richardson et al, 1986). Les fréquences des allozymes des populations tests ont été comparées à l'aide de l'analyse de variance. Entre le 13 mai et le 6 juin, 38 colonies sauvages ont été repérées dans la zone étudiée $\left(12,5 \mathrm{~km}^{2}\right)$. Vingt et une colonies ont été tuées, ou sérieusement endommagées, par les traitements entre le 27 mai et le 5 juin. La pluie survenant l'après-midi durant la période de destruction a empêché la destruction par les mâles. L'augmentation de la miellée a porté préjudice au succès des traitements à l'acéphate. Cinq des 23 caractères morphologiques ont été décalés de façon significative vers la race européenne après l'élimination, dont 2 des 5 caractères les plus discriminants (tableau I). Un nombre significativement plus grand de colonies a été classé comme européennes par l'analyse discriminante multivariée $\left(P_{\mathrm{A}}<0,50\right)$ après l'élimination ( $85 \%$ ) qu'avant $(63 \%)$. À la probabilité de $P_{\mathrm{A}} \geq 0,99 \%, 30 \%$ des colonies étaient africanisées avant l'élimination et seulement $12 \%$ après. Chez les mâles les fréquences des 2 allozymes ont été significativement décalées après l'élimination dans le sens de la répartition européenne. La malate déhydrogénase a diminué de $26 \%$ et l'héxokinase a augmenté de $43 \%$ (tableau II). Le test a montré que l'élimination des colonies possédant des mâles indésirables à proximité de ruchers d'élevage commerciaux a profité au programme de maintien de la souche d'élevage. La destruction de colonies pendant la saison favorable peut épauler d'autres méthodes de contrôle des accouplements (par exemple une offre surabondante des mâles souhaités et le contrôle de la période d'accouplement), mais elle n'est vraisemblablement pas adaptée comme méthode exclusive pour parvenir au contrôle des accouplements dans les régions où cela est nécessaire.

abeille africanisée / contrôle accouplement / lute anti-nuisible / avermectine / acéphate

\section{Zusammenfassung - Dezimierung von freilebenden afrikanisierten Bienen, um eine bessere Paarungskontrolle bei den europäischen Königinnen zu erreichen. Wir prüften ein Programm, das ohne allzu großen Aufwand die freilebenden Völker der afrikanisierten Bienen in der Umgebung}


dezimieren soll. Ziel war es, die Paarungskontrolle bei europäischen Königinnen zu verbessern, die in einem Gebiet mit afrikanisierten Bienen gezüchtet werden. Der Test hatte 3 Phasen: 1) Vor der Dezimierung: Paarungen der europäischen Königinnen erfolgten in Gegenwart der normalen Anzahl afrikanisierter Drohnen und einer geringen Population europäischer Drohnen aus Wirtschaftsvölkern; 2) während der Dezimierung: der Prozess war der: wegen experimenteller Einschränkungen von kurzer Dauer; 3) nach der Dezimierung: Paarungen der Königinnen erfolgten bei einer auf niedrigem Niveau gehaltenen europäischen Drohnenpopulation. Freilebende Völker im Umkreis eines kommerziellen Zuchtbetriebes bei Belén, Guanacaste Province, Costa Rica wurden geortet. Drei Methoden wurden zur Vernichtung benutzt. Eine gebietsumfassende Völkenvernichtung wurde durch Verteilung einer Avermectin-Ivermectin $(0,37 / 0,63)$ Paste per Hand auf die Tergite der Drohnen (144 $\mu \mathrm{g}$ aktive Substanz von Avid ${ }^{\circledR}$ und Zimecterin $\left.{ }^{(}\right)$pro Drohn) versucht. Diese waren mit Luftnetzen (Loper and Sudgen, 1992) gefangen worden. Zugängliche verbliebene Völker wurden direkt mit einem Pyrethroid-Aerosol gesprüht. Nicht zugängliche Völker wurden behandelt, indem man Sammelbienen 500- oder 1000 ppm Acephate (Orthene ${ }^{\circledR} 75 \mathrm{~S}$ ) in Honig-Zucker Sirup als Köder eintragen ließ (Williams et al, 1989; Danka et al, 1992). Der Paarungserfolg von Königinnen nach der Dezimierung ( $n=26$ ) wurde mit dem der Königinnen vor der Dezimierung $(n=27)$ verglichen. Als Referenz dienten Königinnen von afrikanisierten Bienen aus der Umgebung ( $n=35)$ und von importierten europäischen Völkern $(n=23)$. Die Paarungskontrolle wurde mit 2 Methoden abgeschätzt: Zuerst bestimmten wir 23 morphologische Eigenschaften von 10 Arbeiterinnen pro Volk. Die Messungen für jede Eigenschaft wurde mit den 4 Populationen der Versuchsvölker durch Varianzanalyse verglichen. Die Wahrscheinlichkeit der Afrikanisierung $\left(P_{\mathrm{A}}\right)$ jeder dieser Populationen wurde mit der multivariaten Diskriminanz Analyse (Rinderer et al, 1993) klassifiziert. Zweitens bestimmten wir die Frequenz der Allozyme der Malatdehydrogenase- $1^{100}$ und Hexokinase- $1^{100}$ mit Zellulose-Acetat Gelen (Richardson et al, 1986). Die Allozym-Frequenz der TestPopulationen wurden mit Hilfe der Varianzanalyse verglichen. Zwischen dem 13 Mai und 6 Juni wurden bei der Kontrolle 38 freilebende Völker in dem $12,5 \mathrm{~km}^{2}$ großen Versuchsgelände entdeckt. 21 dieser Völker wurden durch die Behandlungen zwischen dem 27 Mai und 5 Juni getötet oder deutlich geschädigt. Regen am Nachmittag während der Vernichtungszeit behinderte die Vernichtung durch die Drohnenbehandlung. Die Zunahme der Tracht beeinträchtigte den Erfolg der Acephate Behandlungen. 5 von 23 morphologische Eigenschaften verschoben sich signifikant zu der europäischen Rasse nach der Dezimierung. Zwei von den 5 am besten zu unterscheidenden Eigenschaften wurden verschoben (Tabelle 1). Signifikant mehr Völker (85\%) wurden nach der Dezimierung mit der multivariaten Diskriminanzanalyse mit $P_{\mathrm{A}}<0,50$ als europäisch klassifiziert als vor der Dezimierung (63\%). Mit einer Wahrscheinlichkeit von $\geq 0,99 \%$ waren vor der Dezimierung $30 \%$ der Völker und nach der Dezimierung $12 \%$ afrikanisiert. Die Frequenzen der beiden Allozyme verschoben sich bei den Drohnen nach der Dezimierung signifikant in Richtung zur europäischen Verteilung. Malatdehydrogenase nahm um $26 \%$ ab und Hexokinase nahm um 43\% zu (Tabelle II). Der Test zeigte, daß die Elimination der Völker mit unerwünschten Drohnen in der Nähe von Zuchtbetrieben dem Programm zur Erhaltung des Zuchtstammes zugute kommt. Vernichtung der Völker während der lokal günstigen Saison kann andere brauchbare Methoden der Paarungskontrolle (zB Überangebot von erwünschten Drohnen und Kontrolle der Paarungszeit) unterstützen. Allerdings ist 
die Vernichtung der Völker allein wahrscheinlich nicht geeignet, um als ausschließliche Methode eine ausreichende Paarungskontrolle in den Gebieten zu erreichen, in denen es notwendig ist.

\section{Afrikanisierte Bienen / Paarungskontrolle / Schädlingsbekämpfung / AcephatKö- der / Avermectin}

\section{REFERENCES}

Daly HV, Balling SS (1978) Identification of Africanized honey bees in the Western hemisphere by discriminant analysis. J Kans Entomol Soc 51, 857-869

Daly HV, Hoelmer K, Norman P, Allen T (1982) Computer-assisted measurement and identification of honey bees (Hymenoptera: Apidae). Ann Entomol Soc Am 75, 591-594

Danka RG, Williams JL, Sugden EA, Rivera R (1992) Field tests of an acephate baiting system designed for eradicating undesirable honey bees (Hymenoptera: Apidae). J Econ Entomo/85, 1104-1111

Del Lama MA, Lobo JA, Soares AEE, Del Lama SN (1990) Genetic differentiation estimated by isozymatic analysis of Africanized honeybee populations from Brazil and from Central America. Apidologie $21,271-280$

Hellmich RL II, Waller GD (1990) Preparing for Africanized honey bees: evaluating control in mating apiaries. Am Bee J 130, 537-542

Hellmich RL II, Collins AM, Danka RG, Rinderer TE (1988) Influencing matings of European honey-bee queens in areas with Africanized honey bees (Hymenoptera: Apidae). J Econ Entomol 81, 796799

Hellmich RL II, Ibarra J, Meija M, Rinderer TE, Gutierrez NA (1993) Evaluating mating control of honey-bee queens in an Africanized area of Guatemala. $A m$ Bee J 133, 207-211

Loper GM, Fierro MM (1991) Use of drone trapping and drone releases to influence matings of European queens in an Africanized honey bee area (Hymenoptera: Apidae). J Apic Res 30, 119-124

Loper GM, Sugden EA (1992) Local Africanized honeybee abatement using drones as insecticide vectors in Costa Rica. Proc 5th Int Conf on Apic in Trop Clim, Trinidad and Tobago, International Bee Research Association, Cardiff, UK

Loper GM, Williams JL, Taylor OR (1987) Insecticide treatment of feral honey bee colonies by treating drones at DCAs. Am Bee J 127, 847

Richardson BJ, Baverstock PR, Adams M (1986) Allozyme Electrophoresis. A Handbook for Animal Systematics and Population Studies. Academic Press, NY, USA

Rinderer TE, Buco SM, Rubink WL et al (1993) Morphometric identification of Africanized and European honey bees using large reference populations. Apidologie 24, 569-585

Taylor OR (1984) An aerial trap for collecting drone honeybees in congregation areas. $J$ Apic Res 23, $18-20$

Waller GD, Hoopingarner RA, Martin JH, Loper GM, Fierro MM (1989) Controlled natural matings of honey-bee queens in southern Arizona. Am Bee $J$ $129,187-190$

Williams JL, Danka RG, Rinderer TE (1989) Baiting system for selective abatement of undesirable honey bees. Apidologie 20, 175-179 